Філіпович Ю. Ю., к.т.н., доцент (Національний університет водного господарства та природокористування, м. Рівне), Філіпович Є. О., завідувачка Музею історії НУВГП, член Національної спілки краєзнавців України, член Національної спілки журналістів України (Національний університет водного господарства та природокористування, м. Рівне)

\title{
ГІДРАВЛІЧНИЙ РОЗРАХУНОК РЕЖИМІВ РОБОТИ ОБОРОННИХ ГІДРОТЕХНІЧНИХ СПОРУД
}

Розглянуто конструкції та режими роботи гідротехнічних споруд та обладнання водяних ровів замків, які являють собою унікальні пам'ятки фортифікаційної архітектури і належать до об'єктів, що потребують детального наукового вивчення для розробки стратегії їх реконструкції, збереження та охорони. Досліджуються гідравлічні характеристики водозаборів, обладнаних щитами (затворами) та шандорними загородженнями.

Ключові слова: фортифікація, військова гідротехніка, бастіони, оборонний рів, вал.

Стан проблеми. Оборонні споруди середньовічних фортець та замків включали до свого складу рови, що заповнялися водою. Дані гідротехнічні споруди широко використовувалися як у Європі (замки Бодіам, Кайрфіллі /Британія/, Тронна фортеця в Сучаві /Румунія/, замки Керлаверок /Шотландія/, Калькум, Гуденау /Німеччина/, Белей /Бельгія/, Несвіж /Білорусь/), так і в Україні (Дубенський, Старокостянтинівський, Острозький, Збаразький, Олеський, Підгорецький, Золочівський замки). Оборонні рови до складу фортифікаційного обладнання замків включав архітектор Блез Франціск де Паган. Форти систем де Вілля та де Вобана складалися з системи бастіонів, оточених ровами (сухими або з водою).

Дубенський замок, займаючи домінуюче положення серед архітектурно-історичних об'єктів, є прикладом фортифікаційного будівництва новоіталійської школи, і має ряд специфічних фортифікаційних рішень. Найстаріше відоме картографічне зображення Дубенського замку та м. Дубна, створене мандрівником Ульріхом фон Вердумом у 1671 році, показує оборонний рів замку, що заповняється водою річки Іква. Вхідна частина рову зображена не детально, про 
якісь водоприймальні споруди говорити не можна. Але вони могли існувати, бо як зазначено в [4], Ульріх фон Вердум в деталі заглиблювався не завжди, робив їх по пам'яті і нашвидкуруч. Розміщення усіх монументальних споруд показане у суттєво зміненому, а то й зміщеному вигляді [4].

Через брак архівних даних про достовірність гідрологічного стану на Волині в період XIV-XVII ст. метою статті $€$ моделювання можливості використання нашими предками водних перешкод під час оборони фортеці від ворога: їх наявність посилювала шанси збити раптовість нападу загарбників, які могли з'явитися нізвідки. Кордони князівств мали досить уявні межі, і прив'язувалися лише до певних географічних об'єктів: річок, гірських масивів, лісів, полів, боліт або озер. Зазвичай, їх «охороняли» межові камені або відповідні знаки. Лише на великих дорогах, роз"їздах, біля мостів та переправ постійно були присутні митники. Від них, або посланців від сусідів, могли бути відправлені гінці з вісткою про наближення ворога. Подекуди усе вирішували години. Автори статті поставили перед собою ряд запитань: за скільки часу оборонний рів буде заповнений водою; скільки потрібно для цього води; якими можливими гідротехнічними спорудами користувалися оборонці замку; якої вони були конструкції; 3 якого матеріалу виготовлені; як довго вони служили.

Актуальність. Замкам та фортецям належала одна з провідних ролей при формуванні сил для стримування татарських нападів на волинські землі, виконання опорних функцій у військових діях XVIXVII ст., зберігання значних запасів озброєння, провіанту та скарбів. Оборонні рови та інші гідротехнічні споруди регулярних замків Західної України XVI-XVII ст. являють собою багато в чому унікальні пам'ятки фортифікаційної архітектури і належать до об'єктів, що потребують детального наукового вивчення для розробки стратегії їх реконструкції, збереження та охорони.

Викладення основного матеріалу. Створенням і обороною замків займається фортифікація - галузь військово-інженерного мистецтва, що охоплює теорію і практику укріплення (фортифікаційне обладнання) місцевості, як під час завчасної військово-інженерної підготовки театрів воєнних дій і території держави, так і під час війни, 3 метою підвищення боєздатності армії, збільшення ії бойової ефективності, захисту військ, органів управління, населення та об'єктів господарства від засобів ураження противника. Фортифікаційне обладнання включає зведення комплексів фортифікаційних споруд відповідно до оперативно-стратегічних або тактичних планів [6]. 
Основними елементами типового замку XVI-XVII ст. були: рів (заповнений водою або сухий); насипний або природний пагорб, підвищення, влаштовані задля кращої обороноздатності; внутрішній двір; донжон (головна башта), оборонна вежа, бастіони; захисна стіна або оборонний мур з кренеляжем; брама або ворота, барбакан тощо.

Питаннями захисту замків та фортець з допомогою використання навколишніх водних ресурсів займалася військова гідротехніка прикладний підрозділ гідротехніки, метою якого $є$ створення науково-методичної бази для виконання технічних заходів на воді з метою підвищення обороноздатності споруд або забезпечення успішних бойових дій [7]. В межах військової гідротехніки вивчаються методи розрахунку міцності і стійкості, оцінки статичних та динамічних навантажень, а також принципи конструювання і технологічні особливості гідротехнічних споруд різноманітного призначення. Військова гідротехніка займається вивченням та виконанням відповідних заходів у різних сферах водного господарства. Одночасно перед військовою гідротехнікою ставлять наступні специфічні задачі [8, С. 8]: створення водних загороджень (затоплення і заболочення); використання гідротехнічних об'єктів цивільного призначення (греблі, дамби, водосховища, акведуки) для військових цілей; пристосування водних шляхів для дій річкових флотилій, для перевезення озброєння і військ; влаштування місць стоянок військових флотилій; забезпечення навантаження, розвантаження і ремонту суден; осушення позицій дислокації, місць розташування оборонних споруд, територій військових поселень; боротьба з оповзнями і руйнуванням, що спричиняє вода; боротьба із ґрунтовими водами; забезпечення військових та населення водою за допомогою гідротехнічних споруд.

Водним загородженням називається будь-яка штучна водна перепона для усіх наземних родів військ, що відповідає певним тактико-технічним вимогам [8, С. 14]. Водне загородження повинне надавати можливість створювати певну економію сил та засобів на ділянках, де воно влаштовується, для зосередження більших сил на інших ділянках, затрудняти або призупиняти на певний час рух військ ворога і заставляти його втрачати час на розвідку і застосування інженерних засобів для переправи військ та озброєння. Проектування і створення водних загороджень частіше виконується на малих річках, оскільки великі річки самі по собі відіграють роль значної водної перешкоди. На невеликих річках витрати води незначні, тому під час проектування на них водних загороджень (під час бойових дій) значну роль відіграє час наповнення захисних ровів, тобто 
час, після якого водяна перешкода стає діючою.

Для вирішення цієї задачі потрібно знати [8, С. 87]: природний стік річки у різні періоди (повінь, паводок, межень); характеристики рову (водосховища); втрати води із рову (водосховища); втрати води на господарські потреби (водопостачання навколишніх поселень, водопій худоби, полив городів, на водяні млини тощо). Перед проектуванням і будівництвом водних перешкод і створення проекту водного загородження у цілому потрібно виконати гідрологічні, топографічні, інженерно-геологічні та виробничо-будівельні вишукування [8, С. 121].

Напір у річці в XVI-XVII ст. створювався за допомогою дерев'яних, земляних або дерев'яно-земляних гребель [8].

Схема дерев'яної греблі з високим порогом наведена на рис. 1.
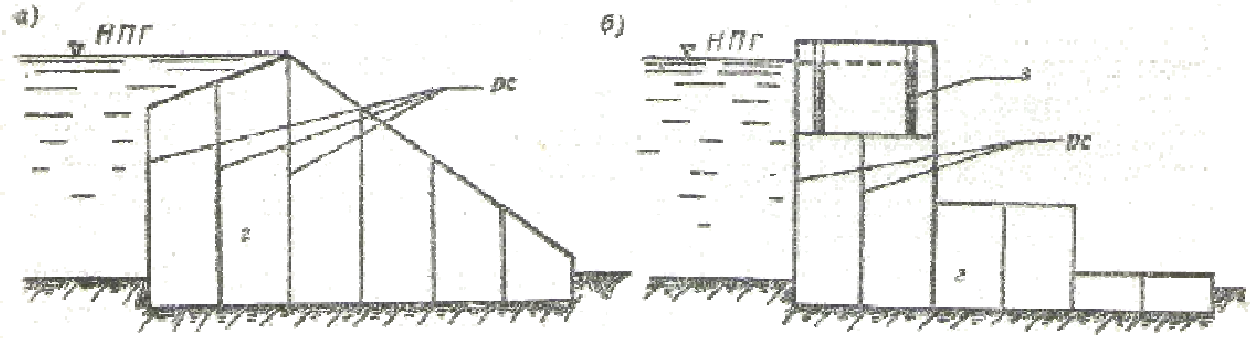

Рис. 1. Схема дерев'яної греблі з високим порогом

Дерев'яна гребля складається із ряжевих стінок (рс) - тобто дерев'яних зрубів, що занурюються в землю, і ґрунту (г), який заповнює ряжеві ящики. Греблі можуть виконуватись без затвору на гребені греблі (рис. 1, а), або із затворами (з) (рис. 1, б).

У випадку греблі без затворів на гребені (рис. 1, а), спорожнення рову (водосховища) виконується донними або глибинними водоспусками. Ці водоспуски влаштовують у глухій дерев'яній частині. Якщо на гребені дерев'яної греблі передбачено установку затворів, то профіль водозливної частини влаштовувався ступінчастим (рис. 1, б). Профілі глухих ділянок греблі виконували такими ж, як і водозлиBнi.

При розрахунку пропуску води із рову може виникнути два випадки [8, С. 116]: випуск води із рову виконується через проран, що виник під час руйнування частини гідровузла, або випуск води виконується через водоскидні отвори з допомогою маневрування щитами або шандорами.

Пристроями для регулювання подачі води із річки до рову були плоскі дерев'яні щити або шандори [8, С. 220-221]. Щити виконува- 
лися із обрізаних дошок, щільно підігнаних між собою в шпунт або четверть, і з'єднаних шпонками, що встановлюються у пази, вибрані у дошках з напірної сторони (рис. 2). Для маневрування щитами до них цвяхами прикріплювалися планки із залізних смуг із гаками зверху.

При ширині отвору між стійками від 2 до 4 метрів, для його закриття використовувалися шандори (рис. 3), які являють собою горизонтальні балки, що закладаються одна на іншу у пази биків. Шандори передають тиск на бики або на контрфорси. Піднімаються шандори за допомогою двох гаків, врізаних у верхню грань.

Найбільш простим підйомником для щитів був во́ротовий підйомник нерухомого або рухомого типу. Усі греблі, що влаштовувалися для створення водних перешкод, оснащувалися підйомниками для забезпечення відкриття водозливних отворів за мінімально короткий строк. Рухомий ворот передає навантаження на міст. Він влаштовується на рамі, установленій на колеса, які пересуваються спеціальними балками.

Заходами, що повністю або частково підвищують ефективність водних перешкод $\epsilon$ [8, С. 103]: збільшення кількості ровів; влаштування каналів і ям, заповнених водою; регулювання водопостачання на господарські потреби; влаштування проміжних валів і гребель.

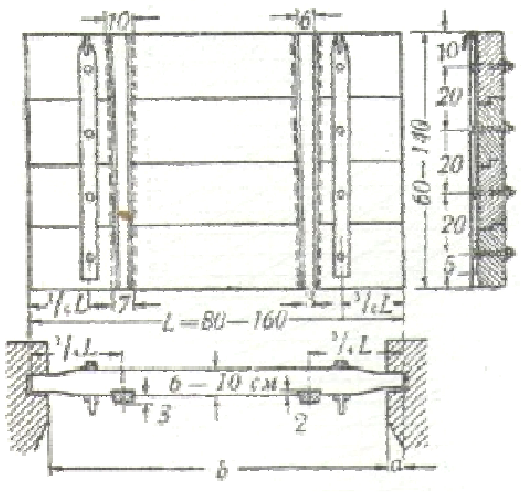

Рис. 2. Схема щита із дошок
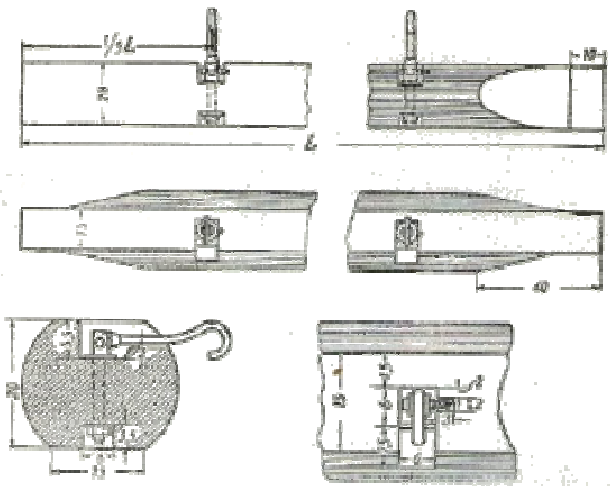

Рис. 3. Схема дерев'яних шандорів

Дубенський замковий комплекс набрав сучасного вигляду на початку XVII ст. завдяки значній реконструкції, яку здійснив князь Януш Острозький. У XVII ст. будуються бастіонні регулярні замки, що поєднують цивільну та військову функції, які в подальшому трансформувалися у «palazzo in fortezzo» - палац у фортеці. Замки цього типу мали стійкий до потужного артилерійського вогню ескарповані іззовні та із середини земляні вали-куртини, а з флангів - бастіони. Усі бастіонні замки оточувався по периметру ровом шириною 7...12 м. 20 
Більшість із ровів мали контрескарп. До в"їзної брами через рів перекидався підвісний міст [5]. В"їзна брама влаштовувалася по центру однієї з куртин (у надбрамній вежі).

Було добудовано два бастіони зі сторожовими вежами. Між старим городищем і новим замком пролягав глибокий рів, який при потребі легко заповнювався водами Ікви. Другий (ширший і важливіший для оборони) рів було вирито з протилежного боку замку. Східний його схил утворювався фасадами бастіонів і куртиною, що їх з'єднувала, а висока прямовисна стіна з боку міста була складена 3 «дикого» каміння. Цей рів також наповнювався водою. Рівень води в оборонних ровах міг сягати 2,5 м. Дно ровів було вимощене каменем. Рили рови при князі Януші Острозькому полоненні татари [5].

Одним із секретів неприступності замку були особливості місцевості. Багатокілометрові заплави поблизу чудово захищали замок. Важкій артилерії ворогів просто неможливо було підібратись через протяжні болота до стін фортеці, тому Дубенський замок увійшов в історію як один із найстійкіших. Протягом п'яти століть його ні разу не взяли штурмом. Та спроб захоплення фортеці було немало - лише протягом XVII століття на місто нападали близько ста разів. Оборонний рів Дубенського замку з валом (рис. 4) мав типову для XVI ст. форму [9].

Дубенський замок стоїть на березі річки Ікви, бастіонний фронт його звернений на північ, а з півдня і сходу він омивається водами річки Ікви та її невеликої притоки Липки.

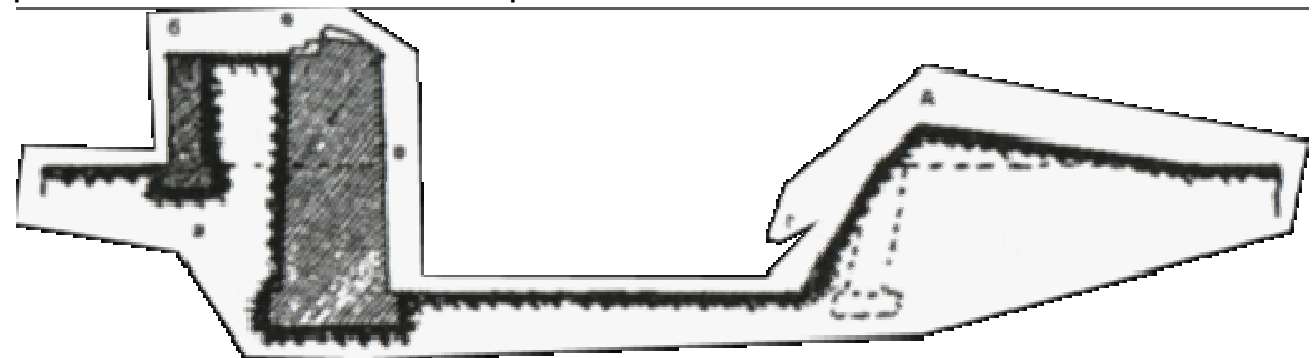

Рис. 4. Профіль валу в середині XVI ст. (взято із [9]):

а - вал; б - валганг; в - ескарп; г-контрескарп; д - гласис; е - банкет

У зв'язку з цим, з південного боку влаштовували незначні укріплення - ворог не міг підступити болотистою місцевістю, перерізаною річкою. Укріплення замку являє собою трапецію з нерівною меншою стороною, і має лише два бастіони. Дубенський замок має високі кам'яні облицювання, великі гострокутні бастіони із влаштованими на них кавальєрами. Бастіонний фронт прикритий ровом 3 опорядженим контрескарпом. Скоріше за все, перед ровом був гласіс 
(оборонна споруда, пологий насип, що зводився перед ровом або прикритим шляхом, і служив захистом укріплення та перешкодою для ворога при наступі на головний вал, а також покращував маскування фортифікаційної споруди та обстріл місцевості перед нею) і прикритий шлях, оскільки в усіх фланках (невеликих прямолінійних ділянках фортечної огорожі, або польових укріплень, приблизно перпендикулярних фронту і призначених для захисту і обстрілу підступів з боку ворога до сусідніх будівель) є проходи, що ведуть до рову, сполучені ходами із замковим подвір'ям [9].

Бастіони замку нетипової форми - це великі, витягнуті верки (окремі укріплення, що входять до складу споруд фортеці, які здатні вести самостійну оборону) з дуже гострим висхідними кутом, рівним $60^{\circ}$. На них були влаштовані кавальєри - підвищені позиції [9]. Особливістю цієї фортифікації $\epsilon$ кам'яне облицювання, викладене з двох матеріалів - каменю і цегли. Ескарп до карнизу викладений з каменю, а вище - обмурований цеглою. Довжина куртини північного бастіонного фронту - 160 м. Посередині ії влаштовано ворота з просторим надбрамним корпусом із двома крилами.

Цікаво було б знати місця, де саме були встановлені гідротехнічні споруди - їх вид, тип, способи їхньої охорони та оборони (для подальшої реконструкції у майбутньому, щоб у музеї-фортеці з'явився новий екскурсійний об'єкт). Метою даної роботи є своєрідний місток між теоретичними дослідженнями та реалізацією їх на практиці.

За топографічними даними плану замку (див. рис. 6 при відомому масштабі) було обчислено площу оборонного рову $F p=6711,29 \mathrm{M}^{2}$. Глибину води у рові прийнято $h_{p}=2,50$ м. Об'єм води, яку необхідно набрати, щоб наповнити рів становить $W_{p}=16788,2 \mathrm{M}^{3}$. Усі інші геометричні характеристики були прийняті довільно за існуючими водозливами-аналогами.

Прикладом замку, у вхідній частині рову якого влаштована водоприймальна споруда, є замок Калькум на півночі землі Дюссельдорф у Німеччині [2]. Рів наповнюється через водоприймальні отвори, оснащені затворами. На даний час вони обслуговуються сучасними гідропідйомниками. Найбільш простим підйомником для щитів і шандорів у Середньовіччі був воротовий підйомник.

Було створено модель головної водозабірної споруди (М 1:50), яка могла влаштовуватися на вході із річки у рів (рис. 5). Водозабір виконаний у формі ряжевих ящиків, заповнених грунтом. Він оснащений двома видами затворів: щитом і шандорним перекриттям $(2 \times 3$ м), які встановлені у пазах водоприймальної споруди. Обслуго- 
вуються затвори підйомним механізмом (наприклад, воротовим підйомником). Для виконання ремонтних робіт передбачено зйомні драбини.
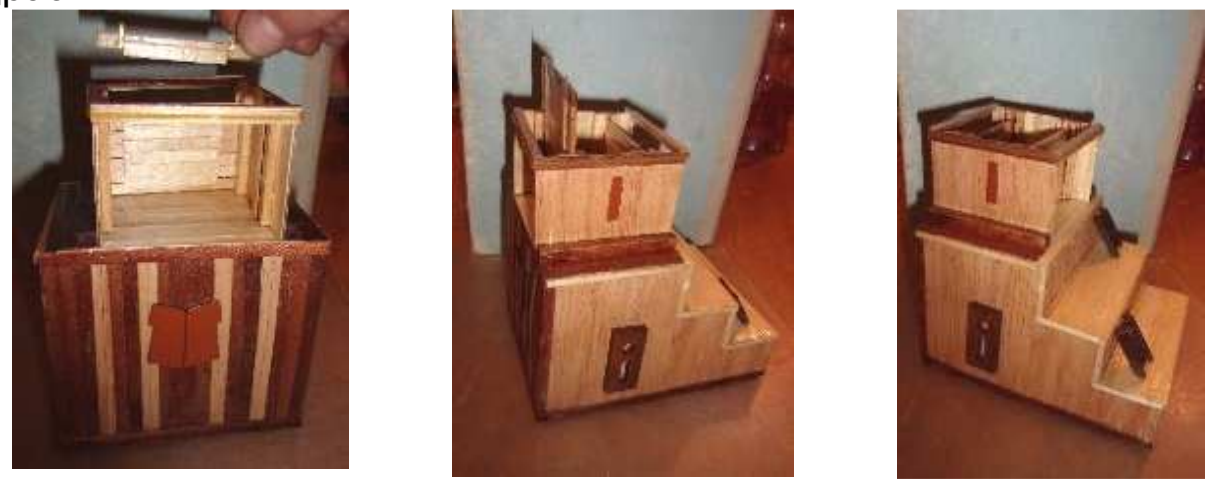

Рис. 5. Модель головної водозабірної споруди, яка могла влаштовуватися на вході із річки у рів (М 1:50)

Водозливом називається перешкода, через яку відбувається перетікання води [11]. Ділянка, на якій безпосередньо відбувається перетікання води, називається порогом водозливу.

За принципом роботи дана споруда відноситься до бокових безгребельних водозаборів.

Безгребельні водозабори з боковим відведенням води будуються за різними схемами [11]: без головної споруди, із головною спорудою, з відстійником і регулюючою спорудою тощо (рис. 6).
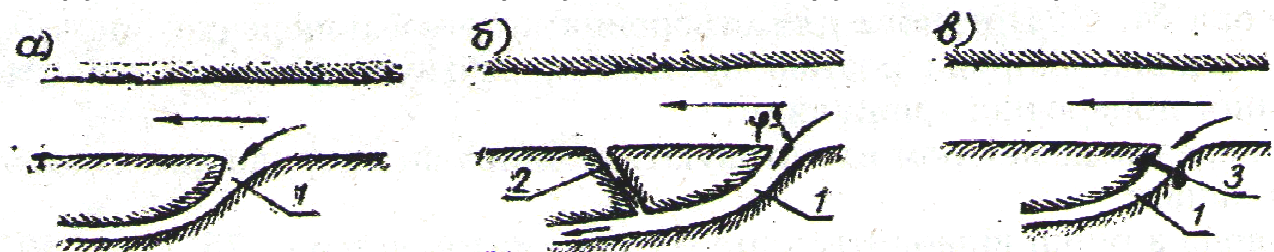

Рис. 6. Схеми бокових безгребельних водозаборів:

а та б - без головної споруди; в - із головною спорудою;

1 - річка (канал); 2 - скидний канал; 3 - головна споруда

Для визначення часу наповнення оборонного рову було виконано розрахунки для двох видів затворів: щита і шандорного перекриття.

У випадку водозабору без головної споруди (рис. 6, а та 6, б) витрата води визначається за формулою Шезі

$$
Q=\omega \cdot C \cdot \sqrt{R \cdot i}, M^{3} / \mathrm{c},
$$

де $\omega$ - площа живого перерізу, м²; $C$ - коефіцієнт Шезі; $R$ - гідравлічний радіус, м; $i-$ похил поверхні води. 
Переливання через шандорне перекриття (водозлив із тонкою стінкою, рис. 6, в). При вільному перетіканні у випадку непідтопленого водозливу витрата води рівна

$$
Q=\varepsilon \cdot m \cdot b \cdot \sqrt{2 \cdot g} \cdot H_{0}^{3 / 2}, M^{3} / c,
$$

де $\varepsilon$ - коефіцієнт бокового стиснення, $\varepsilon=1-\alpha \cdot \frac{H}{H+b} ; H$ - напір над шандорами, $H \approx 0,5$ м; $b$ - ширина прольоту (шандора), м; $\alpha$ - коефіцієнт форми входу - для зворотньої стінки за [12] (рис. 4.18, а) $\alpha=0,2$; $m$ - коефіцієнт витрати, визначений за формулою Базена

$$
\begin{gathered}
m=0,405+\frac{0,003}{H}=0,405+\frac{0,003}{0,5}=0,411 ; \\
\varepsilon=1-0,2 \cdot \frac{0,5}{0,5+2}=0,96 ; \\
Q=0,96 \cdot 0,411 \cdot 2 \cdot \sqrt{2 \cdot 9,81} \cdot 0,5^{3 / 2}=1,24 \mathrm{M}^{3} / \mathrm{c} .
\end{gathered}
$$

Час наповнення водосховища (без врахування втрат на випаровування, фільтрацію, водоспоживання) у цьому випадку визначається за залежністю

$$
t=\frac{W_{p}}{86400 \cdot Q}=\frac{16788,2}{86400 \cdot 1,24}=0,175 \text { доби } \approx 3 \text { год. } 46 \text { хв. }
$$

Витікання 3-під щита. При вільному витіканні, коли рівень води у нижньому б'єфі (рові) не впливає на характер витікання витрата рівна

$$
Q=\varepsilon \cdot \varphi \cdot \varepsilon_{b} \cdot h_{m} \cdot b \cdot \sqrt{2 \cdot g \cdot\left(H_{0}-\varepsilon_{b} \cdot h_{u}\right)}, M^{3} / c
$$

де $\varepsilon$ - коефіцієнт бокового стиснення $\varepsilon=1-\alpha \cdot \frac{H}{H+b} ; \alpha$ - коефіцієнт форми входу - для зворотньої стінки за [12] (рис. 4.18, а) $\alpha=0,2 ; \varphi-$ коефіцієнт швидкості, приймається за рекомендаціями М.М. Павловського $[12$, С. 175$]$ для щитового отвору $\varphi=0,95 \ldots 1,0 ; \varepsilon_{в}-$ коефіцієнт вертикального стиснення за даними М.Є. Жуковського [12, С. 175] при $h_{m} / H=0,5 / 1,5=0,333$ становить $\varepsilon_{B}=0,6274 ; h_{щ,} \approx 0,50$ м - висота відкриття щита; $H_{0}$ - напір перед щитом, $H \approx 1,5$ м; $b$ - ширина прольоту (щита), м

$$
\varepsilon=1-0,2 \cdot \frac{0,5}{0,5+2}=0,96
$$




$$
Q=0,96 \cdot 0,95 \cdot 0,6274 \cdot 0,5 \cdot 2 \cdot \sqrt{2 \cdot 9,81 \cdot(1,5-0,6274 \cdot 0,5)}=2,76^{\mathrm{M}^{3}} / \mathrm{c} \text {. }
$$

Час наповнення водосховища (без врахування втрат на випаровування, фільтрацію, водоспоживання) у цьому випадку визначається за залежністю

$$
t=\frac{W_{p}}{86400 \cdot Q}=\frac{16788,2}{86400 \cdot 2,76}=0,070 \text { доби } \approx 1 \text { год. } 41 \text { хв. }
$$

Висновки. Порівнюючи результати розрахунків, бачимо, що час наповнення оборонного рову у випадку витікання з-під щита (при застосуванні у якості перегороджуючої споруди щитів) майже вдвічі менший, ніж у випадку переливання води через шандорні перекриття.

1. Дубенський замок. URL: https://zamokdubno.com.ua (дата звернення: 15.03.2019). 2. Замок Калькум, окружённый водяным рвом, Дюссельдорф, Германия. URL: https://www.youtube.com/watch?v= 1eXOuAIOj10. (дата звернення: 15.03.2019). 3. Пшеничний Ю. Дубенський замок. Матеріали до характеристики добастіонного періоду. Дубенський науковий вісник : матеріали міжнародної науково-теоретичної конференції, присвяченої 525-річчю Дубенського замку і 100-річчю від дня народження І. Д. Лозов'юка. Вип. 1. Дубно, 2017. С. 29-43. 4. Пшеничний, Ю. Карта Дубна 1671 року Ульріха фон Вердума. Історія музейництва, пам'яткоохоронної справи, краєзнавства і туризму в Острозі та на Волині. Науковий збірник. 2009. Вип. 2. С. 245-250. 5. Дубно (7 Чудес Рівненщини) - Дубенський замок+історія. URL: https://www.youtube.com/watch?v=kWUo78XnQUs\&t=403s. (дата звернення: 15.03.2019). 6. Фортифікація. URL: https://uk.wikipedia.org/wiki/\%D0\%A4\%D0\%BE\%D1\%80\%D1\%82\%D0\% B8\%D1\%84\%D1\%96\%D0\%BA\%D0\%B0\%D1\%86\%D1\%96\% D1\%8F. (дата звернення: 15.03.2019). 7. Военная гидротехника. URL: https://ru.wikipedia.org/wiki/\%D0\%92\%D0\%BE\%D0\% B5\%D0\%BD\%D0\%BD\% D0\%B0\%D1\%8F_\%D0\%B3\%D0\%B8\%D0\%B4\%D1\%80\%D0\%BE\%D1\%82\%D0\%B 5\%D1\%85\%D0\%BD\%D0\%B8\%D0\%BA\%D0\%B0. (дата звернення: 15.03.2019). 8. Дворяшин В. И. Военная гидротехника (водные заграждения). М. : Издание Военно-инженерной академии, 1955. 443 с. 9. Глушок О. В. Еволюція фортифікації на Правобережжі під впливом змін у тактиці облоги (XV-XVII ст.) : монографія. К. : Унів. вид-во “ПУЛЬСАРИ”, 2009. 124 с. 10. Справочник по гидравлике / под ред. Большакова А. А. К. : «Вища школа», 1977. 280 с. 11. Гідротехнічні споруди : підручник для вузів / за ред. Дмитрієва А. Ф. Рівне : Вид-во НУВГП, 1999. 328 с.

\section{REFERENCES:}

1. Dubenskyi zamok. URL: https://zamokdubno.com.ua (data zvernennia: 
15.03.2019). 2. Zamok Kalkum, okruzhennyi vodianym rvom, Diusseldorf, Hermaniia. URL: https://www.youtube.com/watch?v=1eX0uAI0j10. (data zvernennia: 15.03.2019). 3. Pshenychnyi Yu. Dubenskyi zamok. Materialy do kharakterystyky dobastionnoho periodu. Dubenskyi naukovyi visnyk : materialy mizhnarodnoi naukovo-teoretychnoi konferentsii, prysviachenoi 525-richchiu Dubenskoho zamku i 100-richchiu vid dnia narodzhennia I. D. Lozoviuka. Vyp. 1. Dubno, 2017. S. 29-43. 4. Pshenychnyi, Yu. Karta Dubna 1671 roku Ulrikha fon Verduma. Istoriia muzeinytstva, pamiatkookhoronnoi spravy, kraieznavstva i turyzmu v Ostrozi ta na Volyni. Naukovyi zbirnyk. 2009. Vyp. 2. S. 245-250. 5. Dubno (7 Chudes Rivnenshchyny) - Dubenskyi zamok +istoriia. URL: https://www.youtube.com/watch?v=kWUo78XnQUs\&t=403s. (data zvernennia: 15.03.2019).

6.

Fortyfikatsiia.

URL: https://uk.wikipedia.org/wiki/\%D0\%A4\%D0\%BE\%D1\%80\%D1\%82\%D0\% B8\%D1\%84\%D1\%96\%D0\%BA\%D0\%B0\%D1\%86\%D1\%96\% D1\%8F. (data zvernennia: 15.03.2019). 7. Voennaia hidrotekhnika. URL: https://ru.wikipedia.org/wiki/\%D0\%92\%D0\%BE\%D0\% B5\%D0\%BD\%D0\%BD\% D0\%B0\%D1\%8F_\%D0\%B3\%D0\%B8\%D0\%B4\%D1\%80\%D0\%BE\%D1\%82\%D0\%B 5\%D1\%85\%D0\%BD\%D0\%B8\%D0\%BA\%D0\%B0. (data zvernennia: 15.03.2019). 8. Dvoriashin V. I. Voennaia hidrotekhnika (vodnye zahrazhdeniia). M. : Izdanie Voenno-inzhenernoi akademii, 1955. 443 s. 9. Hlushok 0. V. Evoliutsiia fortyfikatsii na Pravoberezhzhi pid vplyvom zmin u taktytsi oblohy (XV-XVII st.) : monohrafiia. K. : Univ. vyd-vo "PULSARY", 2009. 124 s. 10. Spravochnik po hidravlike / pod red. Bolshakova A. A. K. : «Vishcha shkola», 1977. 280 s. 11. Hidrotekhnichni sporudy : pidruchnyk dlia vuziv / za red. Dmytriieva A. F. Rivne : Vyd-vo NUVHP, 1999. 328 s.

Filipovych Yu. Yu., Candidate of Engineering (Ph.D.), Associate Professor (National University of Water and Environmental Engineering, Rivne), Filipovych Ye. O., Head of the Museum of History of NUWEE, Member of the National Union of Local History of Ukraine, Member of the National Union of Journalists of Ukraine (National University of Water and Environmental Engineering, Rivne)

\section{HYDRAULIC CALCULATION OF THE OPERATION MODES OF DEFENSE HYDROTECHNICAL CONSTRUCTIONS}

The constructions and operating modes of defense hydraulic structures and equipment of water moats of castles, which are unique memorials of fortification architecture, and belonging to objects that need scientific research to develop strategies for their reconstruction, preservation and protection, are considered. The hydraulic characteristics of defense ditches equipped with shields (gates) and 
tread barriers are investigated. Defensive structures of medieval fortresses and castles included in the composition of the ditches filled with water. To determine the time of filling the defensive raft, calculations were made for two types of gates: a shield and a shadhor overlap. Comparing the results of the calculations, we see that the time of filling the defense raft in the case of leakage from under the shield (when applied as a barrier shield construction) is almost twice lower than in the case of water transfusion through shandor roofs. Keywords: fortification, military hydraulic engineering, bastions, defensive ditch, shaft.

Филипович Ю. Ю., к.т.н., доцент (Национальный университет водного хозяйства и природопользования, г. Ровно), Филипович Е. А., заведующая Музеем истории НУВХП, член Национального союза краеведов Украины, член Национального союза журналистов Украины (Национальный университет водного хозяйства и природопользования, г. Ровно)

\section{ГИДРАВЛИЧЕСКИЙ РАСЧЕТ РЕЖИМОВ РАБОТЫ ОБОРОННЫХ ГИДРОТЕХНИЧЕСКИХ СООРУЖЕНИЙ}

Рассмотрены конструкции и режимы работы оборонительных гидротехнических сооружений и оборудования водяных рвов замков, представляющие собой уникальные памятки фортификационной архитектуры, и принадлежащих к объектам, нуждающимся в научных исследованиях для разработки стратегии их реконструкции и сохранности. Исследуются гидравлические характеристики водозаборных сооружений, оборудованных щитами (затворами) и шандорными заграждениями.

Ключевые слова: фортификация, военная гидротехника, бастионы, оборонный ров, вал. 